\title{
MARKOV CHAIN ANALYSIS, METODE ALTERNATIF DALAM MENGUKUR TINGKAT ELEKTABILITAS PESERTA PEMILU MELALUI TAGAR: STUDI KASUS PEMILIHAN PRESIDEN INDONESIA TAHUN 2019
}

\author{
Fara Inka Durrah, Samsul Anwar, dan Latifah Rahayu Siregar \\ Jurusan Statistika, Fakultas Matematika dan Ilmu Pengetahuan Alam, Universitas Syiah Kuala \\ E-mail: samsul.anwar@unsyiah.ac.id
}

\begin{abstract}
ABSTRAK.
Tingkat elektabilitas merupakan informasi yang sangat penting bagi peserta pemilihan umum (pemilu) baik calon legislatif maupun eksekutif. Selama ini, elektabilitas seorang kandidat diukur melalui survei yang dilakukan beberapa waktu sebelum masa tenang pemilihan. Selain membutuhkan biaya yang besar, terdapat rentang waktu antara survei dengan hari pemungutan suara sehingga hasilnya berpotensi bias. Oleh karena itu, dibutuhkan sebuah metode alternatif yang dapat digunakan sebagai pembanding dari hasil survei elektabilitas. Penelitian dengan memanfaatkan informasi melalui media sosial menjadi semakin relevan seiring dengan semakin banyaknya pengguna media sosial di Indonesia. Salah satu pendekatan yang cukup menjanjikan dalam mengukur elektabilitas peserta pemilu dengan memanfaatkan media sosial adalah Markov Chain Analysis (MCA). Selain berbiaya rendah, MCA juga dapat mengukur tingkat elektabilitas pada hari pemungutan suara yang tidak dapat dilakukan melalui survei. Sebagai ilustrasi, penelitian ini mengaplikasikan MCA pada pemilihan presiden (pilpres) 2019. Penelitian ini bertujuan untuk mengukur tingkat elektabilitas terhadap kedua pasangan calon di media sosial melalui tagar utama pendukung masing-masing paslon (\#2019tetapjokowi dan \#2019gantipresiden). Hasil penelitian menunjukkan bahwa pada hari pemungutan suara, diprediksi jumlah penyebutan \#2019gantipresiden di media sosial akan lebih banyak daripada \#2019tetapjokowi. Meskipun berbeda dengan hasil perhitungan resmi pada pilpres 2019, metode MCA merupakan metode alternatif berbiaya rendah yang berpotensi dikembangkan untuk mengukur tingkat elektabilitas peserta pemilu pada masa yang akan datang. Pemilihan dan penambahan tagar yang representatif merupakan kunci penting dalam meningkatkan akurasi hasil analisis MCA.
\end{abstract}

Kata kunci: markov chain analysis; media sosial; pemilihan presiden; tagar; tingkat elektabilitas

\section{MARKOV CHAIN ANALYSIS, AN ALTERNATIVE METHOD IN MEASURING ELECTABILITY LEVEL OF ELECTION PARTICIPANTS THROUGH HASHTAG: CASE STUDY ON THE 2019 INDONESIAN PRESIDENTIAL ELECTION}

\begin{abstract}
.
The electability level is critical information for participants (legislative and executive candidates) in general elections. So far, the electability of a candidate is measured through a survey conducted before the election's cool-off period. In addition to requiring high costs, there is a time lag between a survey and polling day so that the results are potentially biased. Therefore, an alternative method that can be used to compare the results of the electability survey is required. Research by utilizing social media information is becoming increasingly relevant as more users in Indonesia. One promising approach in measuring the electability through social media is Markov Chain Analysis (MCA). Despite being low cost, MCA can also measure the electability on polling day, which cannot be done through the survey. As an illustration, this research applied MCA in the presidential election in 2019. This study aims to measure the electability level for both candidates in social media through each candidate's leading hashtags (\#2019tetapjokowi and \#2019gantipresiden). The results showed that on election day, it was predicted that the number of mentions \#2019gantipresiden in social media would be more frequent than \#2019tetapjokowi. Although it differs from the official results in the 2019 presidential election, the MCA method is a low-cost alternative method that can potentially be developed to measure the electability of election participants in the future. The selection and addition of representative hashtags are an essential key in increasing the accuracy of MCA analysis.
\end{abstract}

Key words: markov chain analysis; social media; presidential election; hashtags; electability level 


\section{PENDAHULUAN}

Indonesia telah berhasil menyelenggarakan pemilihan umum (pemilu) secara serentak untuk pertamakalinya sebagai pesta demokrasi terbesar di dunia dalam pemilihan presiden dan wakil presiden, anggota DPR RI, DPD RI, DPRD Provinsi dan DPRD Kabupaten/Kota untuk periode 2019 - 2024 (Arif, 2019). Triono (2017) menyatakan bahwa gagasan terselenggaranya pemilu serentak pada tanggal 17 April 2019 akan membawa konsekuensi politik secara nasional dan daerah. Pada Pemilihan Presiden (Pilpres) yang kedelapan, Komisi Pemilihan Umum (KPU) telah menetapkan dua pasangan calon (paslon) presiden dan wakil presiden. Kedua paslon tersebut adalah Joko WidodoMa'ruf Amin dengan nomor urut 01 dan paslon Prabowo Subianto-Sandiaga Salahuddin Uno dengan nomor urut 02.

Terdapat perbedaan yang cukup signifikan mengenai komposisi antar kedua paslon. Calon presiden dari paslon 01 berasal dari Partai Demokrasi Indonesia Perjuangan (PDIP), sedangkan calon wakil presiden berasal dari luar partai pengusung dan pendukung. Menurut Alhamid \& Perdana (2018), mekanisme pilpres secara langsung telah mendorong partai politik untuk memilih kandidat yang paling populer meskipun kandidat tersebut merupakan kader luar partai. Sebaliknya, calon presiden dan calon wakil presiden nomor urut 02 merupakan kader dari partai yang sama yaitu dari partai Gerindra. Menurut Nurdiansyah (2018), partai politik memiliki korelasi yang tinggi dengan kekuatan figur publik untuk meningkatkan popularitas dan keterpilihan mereka. Selain itu, paslon 01 merupakan calon petahana, sedangkan paslon 02 merupakan calon yang didukung oleh partai oposisi yang disebut dengan Koalisi Merah Putih (KMP). KMP dibentuk untuk mempertahankan oposisi mereka terhadap pemerintahan Joko Widodo - Jusuf Kalla sejak tahun 2014 (Admojo, 2016). Disisi lain, presiden terpilih yang bukan berasal dari partai pemenang pemilu umumnya akan membentuk koalisi untuk mengamankan kebijakan dan stabilitas politik (Suwarko, 2015). Koalisi partai pemerintah pada era Presiden Joko Widodo-Jusuf Kalla disebut dengan Koalisi Indonesia Hebat (KIH).

Mengetahui tingkat elektabilitas merupakan hal yang sangat penting bagi para kandidat peserta pemilu termasuk paslon peserta pilpres. Elektabilitas tersebut biasanya diukur melalui survei yang dilakukan tim pemenangan maupun lembaga survei independen seperti Cyrus Network, Lingkaran Survei Indonesia, Media Indonesia, Pusat Kajian Kebijakan dan Pembangunan Strategis (Puskaptis), Saiful Mujani Research and Consulting serta beberapa lembaga survei nasional lainnya. Survei elektabilitas dilaksanakan beberapa kali untuk mengamati pergerakan dukungan masyarakat terhadap kandidat yang disurvei. Survei elektabilitas tersebut dilakukan di seluruh provinsi di Indonesia untuk pemilihan presiden dan di daerah pemilihan (dapil) untuk pemilihan calon legistatif maupun kepala daerah. Survei tersebut melibatkan banyak pihak termasuk relawan atau tenaga survei yang terlatih. Survei elektabilitas membutuhkan biasa yang sangat besar dalam pelaksanaannya. Selain berbiaya besar, hasil survei elektabilitas juga berpotensi bias karena adanya efek lag waktu antara hari dilakukannya survei dengan hari pelaksanaan pemungutan suara.

Banyak faktor yang dapat merubah pilihan seorang pemilih terutama pada saat mendekati hari pemungutan suara. Yustiningrum \& Ichwanuddin (2015) menyatakan bahwa rendahnya loyalitas terhadap partai politik serta tidak adanya identitas kepartaian pada seseorang merupakan salah satu faktor psikologis yang menyebabkan mudahnya pemilih untuk berpindah ke partai atau kandidat yang lain.

Elektabilitas seorang kandidat dapat ditingkatkan melalui kegiatan kampanye yang merupakan salah satu rangkaian kegiatan dalam pelaksanaan pemilu. Pada pilpres, kegiatan kampanye berisikan sosialisasi visi dan misi serta program kerja yang akan dilaksanakan oleh masing-masing paslon apabila terpilih sebagai presiden dan wakil presiden nantinya. Menurut Fatimah (2018) kampanye politik menjadi hal yang sangat penting dalam negara yang menganut sistem demokrasi yang bertujuan untuk memperkenalkan kandidat kepada masyarakat.

Pada pemilu serentak 2019, kampanye tidak hanya dilakukan dari mulut ke mulut atau dari satu pintu rumah ke pintu rumah lainnya, melainkan juga sudah memanfaatkan kemajuan dan perkembangan teknologi seperti penggunaan media sosial. Menurut data yang diperoleh dari Statista (2019), sebuah portal online yang 
menyediakan data riset pasar, hingga tahun 2018 tercatat sebanyak 81 juta $(30,26 \%)$ penduduk Indonesia telah menjadi pengguna (user) media sosial dan diperkirakan jumlah tersebut akan terus mengalami peningkatan dan mencapai 103,1 juta pada tahun 2023. Dengan kata lain, saat ini hampir sepertiga penduduk Indonesia telah menggunakan media sosial sehingga penilaian terhadap berbagai aspek kehidupan bermasyarakat termasuk dalam bidang politik dapat dianalisis melalui penggunaan data media sosial tersebut.

Penggunaan media sosial dalam bidang politik telah berkontribusi pada modernisasi proses komunikasi politik. Media sosial menjadi sarana baru yang memungkinkan terjadinya proses komunikasi secara langsung dengan para follower, serta mampu memberikan pengaruh dalam proses pendistribusian pesan-pesan politik yang disampaikan kepada para pemilih. (Deželan \& Vobič 2016)

Dewasa ini, perang tagar merupakan sebuah fenomena menarik dalam proses kampanye pemilihan umum termasuk yang terjadi pada pilpres 2019. Menurut Gunawan (2018), tagar menjadi simbol dalam menggerakkan user media sosial, dan sering digunakan oleh politisi untuk memengaruhi persepsi politik user media sosial khususnya yang menjadi follower mereka. \#2019gantipresiden merupakan tagar andalan bagi pendukung paslon nomor urut 02 yang pertama kali disebutkan oleh Politikus PKS bernama Mardani Ali Sera. Dengan munculnya tagar tersebut, pendukung paslon nomor urut 01 juga memunculkan beberapa tagar untuk menyaingi \#2019gantipresiden.

Data dari http://brand24.com pada minggu kedua bulan Agustus 2018 menunjukkan bahwa \#2019tetapjokowi merupakan tagar dengan jumlah penyebutan terbanyak sebagai bentuk dukungan terhadap paslon nomor urut 01. Sedangkan \#2019gantipresiden merupakan tagar dengan jumlah penyebutan terbanyak untuk paslon nomor urut 02. Brand24 adalah sebuah perusahaan IT yang beroperasi dalam bidang industri informasi teknologi yang berkantor pusat di Polandia. Perusahaan tersebut menyediakan perangkat untuk memonitor aktivitas penggunaan internet dan media sosial termasuk pencarian tagar. Selain itu, Brand24 juga memonitor puluhan ribu produk dari berbagai negara seperti Amerika Serikat, Inggris, Polandia, Indonesia,
Italia, Bulgaria, Kanada, Singapura, Arab Saudi dan Australia. Akibat dari perang tagar pada pilpres tahun 2019, media sosial seperti Twitter, Facebook dan Instagram serta termasuk blog, video, forum, news, dan web dipenuhi oleh tagar dukungan terhadap kedua paslon peserta pilpres 2019. Perang tagar umumnya dilakukan oleh individu yang tergolong ke dalam kelompok relawan dari masing-masing paslon. Menurut Purboningsih (2015), kelompok relawan yang tidak mendukung calon pertahana umumnya dilatarbelakangi oleh kegelisahan dan kekecewaan terhadap kebijakan atau pemerintahan terdahulu.

Data jumlah penyebutan tagar masingmasing kelompok pendukung paslon dalam beberapa bulan sebelum dilaksanakan pilpres menjadi salah satu hal yang menarik untuk diamati pergerakannya. Hal ini dapat dijadikan sebagai salah satu acuan dalam mengukur tingkat elektabilitas paslon pada saat dilakukannya pemungutan suara. Dua tagar dengan trending topic untuk masing-masing kelompok pendukung yang akan dibandingkan dalam penelitian ini adalah \#2019tetapjokowi mewakili pendukung paslon nomor urut 01 dan \#2019gantipresiden mewakili pendukung paslon nomor urut 02. Markov Chain Analysis (MCA) menjadi metode yang dipilih untuk menganalisis hasil perbandingan kedua tagar tersebut.

MCA merupakan suatu metode yang menaksir karakteristik variabel pada masa yang akan datang dengan menggunakan karakteristik variabel di masa sekarang. MCA memiliki sifat khusus yaitu peluang kejadian ke depan hanya bergantung pada peluang kejadian pada saat ini, dan tidak bergantung pada peluang kejadian sebelumnya. Metode ini didefinisikan dalam bentuk matriks peluang transisi yang memuat informasi perpindahan sistem dari suatu state ke state lainnya (Ross, 2012). Hasil yang akan diperoleh dalam analisis ini adalah berupa informasi probabilistik yang dapat digunakan untuk memperkirakan tingkat elektabilitas dan dukungan terhadap paslon peserta pilpres terutama di media sosial pada hari pemungutan suara.

Metode MCA telah banyak digunakan oleh para peneliti untuk menganalisis pergerakan beberapa data. Fathurrahmi \& Jatipaningrum (2016)menggunakankonsep markovchain untuk memprediksi kejadian bencana alam di wilayah 
Indonesia terutama di Provinsi Jawa Tengah dengan memanfaatkan data kejadian bencana alam pada masa lalu. Hasil penelitian tersebut menyimpulkan bahwa angin puting beliung dan banjir merupakan bencana yang paling mungkin terjadi pada bulan Juli dan Agustus tahun 2016. Ndruru (2014) menerapkan MCA untuk mengidentifikasi perubahan indeks harga saham dari sepuluh emitan yang bergabung di Bursa Efek Indonesia (BEI) dengan menggunakan tiga state yaitu naik, tetap dan turun. Penelitian tersebut mampu memprediksi besarnya peluang terjadinya perubahan harga saham (akan naik, tetap atau turun) dari kesepuluh emitan tersebut pada masa yang akan datang. Lakshmi \& Jyothi (2020) menggunakan metode MCA untuk memprediksi kinerja pasar saham di India terutama yang berkaitan dengan sektor minyak dan gas. Penelitian tersebut memanfaatkan informasi pergerakan harga saham pada masa lalu. Mereka menyimpulkan bahwa tiga dari lima saham terkemuka pada sektor minyak dan gas di India berpeluang besar akan mengalami peningkatan harga, sementara dua lainnya akan stabil atau tetap. Selain ketiga penelitian tersebut, terdapat banyak penelitian dalam bidang lainnya yang menggunakan MCA.

Dalam aplikasinya, metode MCA tidak membutuhkan dana dan sumber daya manusia yang besar. Sehingga metode ini dapat menjadi salah satu alternatif dalam mengukur tingkat elektabilitas seorang kandidat. Selain itu, MCA dapat mengukur elektabilitas seorang kandidat pada hari pelaksanaan pemilihan yang tidak mungkin dilakukan melalui survei. Oleh karena itu, penelitian ini mencoba menerapkan metode MCA dalam upaya mengukur tingkat elektabilitas dan dukungan terhadap paslon presiden dan wakil presiden yang ikut dalam pilpres tahun 2019 berdasarkan jumlah dukungan via media sosial. Adapun tujuan penelitian yang ingin dicapai adalah menghitung peluang jumlah penyebutan \#2019gantipresiden akan lebih banyak dibandingkan dengan jumlah penyebutan \#2019tetapjokowi pada hari pemungutan suara. Besarnya peluang jumlah penyebutan salah satu tagar akan lebih banyak dari yang lainnya dapat memberikan gambaran mengenai hasil pemungutan suara yang akan dilakukan. MCA dapat dikembangkan sebagai metode alternatif dalam mengukur tingkat elektabilitas seorang kandidat peserta pemilu maupun pilkada pada masa yang akan datang. Metode alternatif dalam bidang politik dibutuhkan sebagai pembanding terhadap hasil survei elektabilitas dan popularitas yang dilaksanakan oleh sebuah lembaga untuk meminimalisir potensi terjadinya manipulasi tingkat elektabilitas seorang kandidat dalam upaya penggiringan opini publik.

\section{Perilaku dan Preferensi Pemilih}

Konsep perilaku memilih berkaitan erat dengan alasan dan faktor yang menyebabkan seseorang memilih sebuah partai atau kandidat calon legislatif maupun eksekutif yang ikut dalam kontestasi politik. Perilaku pemilih dapat dijelaskan dalam tiga pendekatan utama, yaitu sosiologi, psikologi, dan pilihan rasional. Menurut pendekatan sosiologis, manusia terikat dalam berbagai lingkaran sosial, misalnya keluarga, teman, tempat kerja, dan lain sebagainya. Berdasarkan pemikiran tersebut, Sosiolog Paul F. Lazersfeld, Bernard Berelson dan Hazel Gaudet mengemukakan bahwa preferensi dan perilaku pemilih akan dipengaruhi oleh lingkaran sosial disekitarnya seperti status ekonomi, agama, tempat tinggal, pekerjaan dan lainnya (Roth, 2008). Disisi lain, menurut pendekatan psikologis partisipasi seseorang dalam proses pemilihan umum juga disebabkan karena yang bersangkutan tertarik dengan politik, mempunyai perasaan yang dekat dengan partai politik tertentu, memiliki informasi yang cukup dalam menentukan pilihannya, serta percaya bahwa suaranya berarti dan dapat memperbaiki keadaan (Mujani, Liddle, \& Ambardi 2012). Sedangkan dalam pendekatan pilihan rasional, terdapat dua orientasi yang menyebabkan seseorang memilih yaitu orientasi isu yang berkaitan dengan isu dalam pemecahan persoalan yang ada dalam masyarakat serta orientasi kandidat yang berkaitan dengan sikap pemilih terhadap seorang kandidat tanpa melihat latar belakang partai politik yang mengusungnya (Downs, 1957).

\section{Pengaruh Media Sosial Terhadap Perilaku Pemilih}

Media sosial merupakan salah satu sarana komunikasi berbasis online yang banyak digunakan dewasa ini terutama oleh para generasi muda. Beberapa platform media sosial yang banyak digunakan di Indonesia saat ini diantaranya adalah Twitter, Facebook dan 
Instagram. Media sosial tidak hanya digunakan sebagai media interaksi dan komunikasi, namun juga sebagai sarana menyebarkan informasi dan iklan dalam berbagai bidang termasuk politik. Iklan politik adalah sebuah iklan sosialisasi khalayak yang bertujuan memengaruhi khalayak dalam menentukan pilihan politiknya (Wiryanto, 2000). Diantara ketiga kelompok pemilih, iklan politik melalui media sosial sangat efektif bagi kelompok pemilih yang termasuk dalam kelompok floating voters. Menurut Nimmo (2010), floating voters adalah kelompok pemilih yang masih mengambang karena belum memastikan diri untuk berafiliasi ke calon atau partai politik tertentu. Informasi melalui iklan politik yang mereka terima melalui media sosial dapat memengaruhi sikap dan pilihan politik mereka. Penelitian Haloho, Rembang, \& Waleleng (2016) menunjukkan bahwa pemilih pemula yang termasuk salah satu kelompok floating voters aktif menggunakan media sosial dan menjadikan media sosial sebagai sumber informasi utama pada pemilihan walikota dan wakil walikota Manado tahun 2016. Lebih rinci, penelitian Zinaida \& Maharani (2015) pada Pemilu 2014 di Kota Palembang menunjukkan bahwa Twitter merupakan media sosial yang sangat berpengaruh terhadap perilaku dan sikap politik pemilih pemula.

\section{Politik Tagar di Media Sosial}

Tagar (\#), lakuran dari kata tag dan pagar, adalah salah satu fitur yang pada awalnya diperkenalkan oleh Twitter pada bulan Agustus tahun 2007. Tagar dikembangkan sebagai sarana untuk membuat pengelompokkan di Twitter tanpa harus mengubah layanan dasarnya (Messina, 2010). Seiring berjalannya waktu, penggunaan tagar sudah merambah ke media sosial lainnya termasuk Facebook, Instagram, Tumblr dan lain sebagainya. Menurut Mulyadi \& Fitriana (2018), tagar telah menjadi alat dalam menemukan sumber konten di media sosial, menjadi cara baru dalam gerakan sosial, dan mengubah cara membangun komunitas virtual.

Tagar berfungsi sebagai pengelompokkan konten berdasarkan kata kunci atau frasa yang menyertainya. Hal ini memudahkan user untuk mengikuti topik tertentu di media sosial. Dalam bidang politik, tagar biasanya digunakan untuk mengangkat suatu isu di media sosial, misalnya yang berkaitan dengan kampanye politik.
Selain itu, tagar juga dapat digunakan sebagai bentuk dukungan terhadap sebuah isu yang sedang berkembang. Dengan menyebutkan tagar tertentu, maka user media sosial dapat terkelompokkan sebagai pendukung isu yang diangkat tersebut. Tagar dalam bidang politik cenderung memihak pada kelompok tertentu meskipun frasa yang digunakan bermakna netral. Sebagai contoh \#2019TetapPancasila secara bahasa memiliki makna yang netral, namun akan bermakna berbeda apabila berada dalam konteks kontestasi. Ketika frasa tersebut ditempelkan pada identitas kelompok tertentu, maka makna dasar tersebut akan bergeser. Menurut Puspita (2018), dalam bidang politik tagar tidak hanya merujuk pada sebuah isu yang sedang trending, namun juga terdapat politik labelisasi dibalik tagar tersebut.

\section{METODE}

\section{Data dan Variabel Penelitian}

Penelitian ini merupakan penelitian kuantitatif eksploratif dengan menggunakan data time series untuk mengukur tingkat elektabilitas dan dukungan terhadap paslon peserta pilpres 2019 . Data yang digunakan pada penelitian ini adalah data sekunder yang diunduh dari website http:// brand24.com. Website tersebut menghimpun data jumlah penyebutan \#2019gantipresiden dan \#2019tetapjokowi yang bersumber dari Facebook, Instagram, Twitter, blog, video, forum, news serta web. Penyebutan dalam penelitian ini didefinisikan sebagai segala bentuk unggahan di media sosial yang mengandung unsur tagar, dalam hal ini \#2019tetapjokowi dan\#2019gantipresiden. Data tersebut dihimpun secara online dari user media sosial yang tersebar di seluruh Indonesia, sehingga tidak terbatas pada suatu wilayah atau area tertentu saja. Data yang digunakan merupakan data harian sebanyak 191 observasi yang diambil mulai dari tanggal 20 Agustus 2018 hingga 26 Februari 2019. Data terdiri dari 2 variabel utama yaitu jumlah penyebutan \#2019tetapjokowi dan jumlah penyebutan \#2019gantipresiden. Secara rinci, variabel operasional yang digunakan pada penelitian ini disajikan pada Tabel 1 .

\section{Prosedur Analisis Data}

Penelitian ini menggunakan metode MCA dalam upaya mengukur tingkat elektabilitas peserta pilpres 2019 terutama di 
Tabel 1. Variabel operasional

\begin{tabular}{lll}
\hline Variabel & \multicolumn{1}{c}{ Keterangan } & Skala \\
\hline $\mathrm{T}$ & $\begin{array}{l}\text { Jumlah penyebutan } \\
\text { \#2019tetapjokowi }\end{array}$ & Rasio \\
$\mathrm{G}$ & $\begin{array}{l}\text { Jumlah penyebutan } \\
\text { \#2019gantipresiden }\end{array}$ & Rasio \\
\hline
\end{tabular}

media sosial. Adapun tahapan dalam analisa data yang dilakukan dalam penelitian ini dijabarkan sebagai berikut:

1. Mengeksplorasi data penelitian untuk mengetahui karakteristik dari data jumlah penyebutan \#2019tetapjokowi dan \#2019 gantipresiden yang disajikan dalam ringkasan statistik dan line chart.

2. Menerapkan MCA untuk menganalisa pergerakan jumlah penyebutan \#2019ganti presiden akan lebih banyak dibandingkan dengan jumlah penyebutan \#2019tetapjokowi dengan tahapan-tahapan sebagai berikut:

a. Memilah data penelitian menjadi 161 kelompok.Adapunkelompok data pertama berisikan data selama 30 hari pertama sejak pengumpulan data (tanggal 20 Agustus - 18 September 2018), kelompok kedua berisikan data 31 hari pertama sejak pengumpulan data (tanggal 20 Agustus - 19 September 2018), kelompok ketiga berisikan 32 data dan seterusnya. Data dikelompokkan mulai dari 30 hari pertama didasarkan pada asumsi bahwa ukuran data dikatakan besar apabila memiliki jumlah observasi minimal 30.

b. Menentukanstateyangdigunakan.Terdapat tiga state dalam penelitian ini yaitu state "lebih dari" yang disimbolkan dengan 0 , state "sama dengan" disimbolkan dengan 1, dan state "kurang dari" disimbolkan dengan 2. State 0 digunakan apabila jumlah penyebutan \#2019gantipresiden lebih banyak dibandingkan dengan jumlah penyebutan \#2019tetapjokowi pada waktu yang sama. State 1 digunakan apabila jumlah penyebutan \#2019gantipresiden sama dengan jumlah penyebutan \#2019tetapjokowi, dan state 2 digunakan apabila jumlah penyebutan \#2019gantipresiden lebih sedikit dibandingkan dengan jumlah penyebutan \#2019tetapjokowi pada waktu yang sama.

c. Menyusun matriks peluang transisi. Setelah semua observasi dikategorikan ke dalam state tertentu, tahap selanjutnya adalah menyusun matriks peluang transisi untuk masing-masing kelompok data. Matriks peluang transisi tersebut merupakan matriks dengan ukuran $3 \times 3$ yang merupakan peluang bersyarat pada state $i \quad(i=0,1,2)$ berpindah ke state $j$ $(j=0,1,2)$. Nilai peluang tersebut diperoleh dari jumlah observasi pada state $i$ yang berpindah ke masing-masing state $j$ dibagi dengan total jumlah state $i$ yang berpindah ke statej. Pada tahap ini akan diperoleh 161 matriks peluang transisi yang berukuran $3 \times 3$ dari masing-masing kelompok data.

d. Menghitung peluang jumlah penyebutan \#2019gantipresiden akan lebih dari, atau sama dengan, atau kurang dari jumlah penyebutan \#2019tetapjokowi pada langkah ke- $n\left(\boldsymbol{P}^{n}\right)$ dengan menggunakan persamaan 11, di mana $n$ adalah jumlah langkah sampai hari pelaksanaan pemungutan suara pilpres. Pada tahap ini diperoleh 161 matriks peluang transisi pada hari dilaksanakannya pilpres 2019 (17 April 2019) dari setiap kelompok data.

e. Menghitung nilai rata-rata dan standard error peluang transisi pada langkah ke- $n\left(\boldsymbol{P}^{n}\right)$ dari 161 peluang transisi yang diperoleh pada langkah 2d berdasarkan teori Law of Large Number (LLN). Matriks peluang transisi yang diperoleh pada tahap ini merupakan matriks peluang transisi akhir $\left(\boldsymbol{P}^{H}\right)$ yang akan digunakan dalam menganalisis peluang masingmasing paslon dalam pilpres.

f. Menyusun selang kepercayaan 95\% peluang transisi pada hari pemungutan suara pilpres tahun 2019 dengan menggunakan persamaan 14.

3. Interpretasi hasil MCA dan penarikan kesimpulan.

Sebagai catatan, perbandingan jumlah penyebutan \#2019gantipresiden akan lebih banyak dibandingkan dengan jumlah penyebutan \#2019tetapjokowi digunakan tanpa alasan khusus. Hal ini dikarenakan hanya terdapat dua paslon dalam pilpres 2019. Peluang penyebutan \#2019gantipresiden akan lebih banyak dibandingkan dengan jumlah penyebutan \#2019 tetapjokowi sama artinya dengan peluang penyebutan \#2019tetapjokowi akan lebih sedikit 
dibandingkan dengan jumlah penyebutan \#2019 gantipresiden. Demikian juga sebaliknya, Peluang penyebutan \#2019gantipresiden akan lebih sedikit dibandingkan dengan jumlah penyebutan \#2019tetapjokowi sama artinya dengan peluang penyebutan \#2019tetapjokowi akan lebih banyak dibandingkan dengan jumlah penyebutan \#2019gantipresiden. Peluang jumlah penyebutan \#2019gantipresiden akan lebih banyak dibandingkan dengan jumlah penyebutan \#2019tetapjokowi merupakan komplemen dari peluang jumlah penyebutan \#2019gantipresiden akan lebih sedikit dibandingkan dengan jumlah penyebutan \#2019tetapjokowi, demikian juga sebaliknya. Sehingga, mengetahui peluang salah satu perbandingan akan memberikan informasi mengenai peluang perbandingan yang lainnya. Perbandingan mana pun yang digunakan akan memberikan hasil akhir dan interpretasi yang sama.

Berikut penjelasan singkat mengenai konsep metode analisis data yang digunakan dalam penelitian ini.

\section{Peluang}

Peluang atau probabilitas merupakan ukuran akan terjadi atau tidaknya suatu peristiwa. Himpunan semua kemungkinan hasil suatu percobaan disebut ruang sampel yang dilambangkan dengan huruf $S$. Sedangkan kejadian merupakan suatu himpunan bagian dari ruang sampel. Peluang suatu kejadian $A$ merupakan jumlah semua titik sampel dalam $A$. Kejadian dapat dibedakan menjadi dua jenis, yaitu kejadian sederhana dan kejadian majemuk. Kejadian sederhana adalah kejadian yang hanya terdiri dari satu titik sampel dan dapat dinyatakan sebagai sebuah himpunan. Sedangkan kejadian majemuk merupakan kejadian yang terdiri dari beberapa kejadian sederhana.

Menurut Ross (2012), peluang sebagai fungsi probabilitas kejadian $A$ yang dinyatakan dalam $P(A)$ adalah sebuah fungsi yang memenuhi 3 hal sebagai berikut:

1. $\mathrm{P}$ bernilai non-negatif yang bernilai antara 0 dan $1(0 \leq P(A) \leq 1)$

2. P bersifat normed, yaitu $P(S)=1$, dimana $S$ adalah seluruh kejadian dalam ruang sampel.

3. Untuk sembarang kejadian $A_{j}$ yang saling bebas, maka $P\left(\bigcup_{j=1}^{\infty} A_{j}\right)=\sum_{j=1}^{\infty} P\left(A_{j}\right)$
Peluang sebuah kejadian $A$ adalah perbandingan antara jumlah kejadian $A$ yang disimbolkan dengan $n(A)$ terhadap jumlah seluruh kejadian di dalam sebuah ruang sampel yang disimbolkan dengan $n(S)$, atau secara matematis dapat ditulis dalam persamaan 1 .

$$
P(A)=\frac{n(A)}{n(S)}
$$

\section{Peluang Bersyarat}

Peluang bersyarat dapat didefinisikan sebagai peluang terjadinya suatu kejadian dimana kejadian lainnya sudah terjadi (Ross, 2012). Peluang terjadinya kejadian $B$ dengan syarat kejadian $A$ sudah terjadi dilambangkan dengan $P(B \mid A)$, didefinisiskan sebagai persamaan 2 .

$$
P(B \mid A)=\frac{P(B \cap A)}{P(A)}
$$

dimana $P(B \cap A)$ merupakan peluang kejadian $A$ dan $B$ terjadi, dan $P(A)$ merupakan peluang kejadian $A$.

\section{Markov Chain Analysis}

Markov Chain Analysis (MCA) merupakan sebuah teknik yang dapat digunakan untuk mengetahui peluang kejadian pada masa depan dengan cara menganalisis peluang kejadian pada masa sekarang tanpa memperhatikan peluang kejadian pada masa lalu (Ross, 2012). MCA memiliki sifat khusus yaitu peluang kejadian di waktu yang akan datang $\left\{X_{t+1}\right\}$ hanya bergantung pada peluang kejadian di waktu sekarang $\left\{X_{t}\right\}$ dan tidak bergantung pada peluang kejadian di waktu yang lalu $\left\{X_{t-1}, X_{t-2}, X_{t-3}, \ldots\right\}$. Menurut Ross (2012), pernyataan tersebut dapat ditulis dalam persamaan 3 .

$$
\begin{gathered}
P\left\{X_{t+1}=j \mid X_{0}=k_{0}, X_{1}=k_{1}, X_{t-1}=k_{t-1}, X_{t}\right. \\
=i\}=P\left\{X_{t+1}=j \mid X_{t}=i\right\}
\end{gathered}
$$

dimana $t=0,1,2, \ldots ., n$. Jika $X_{t}(t=0,1,2$, $\ldots ., n)$ merupakan proses acak yang memiliki kemungkinan untuk dihitung nilainya, maka $X_{t}=i$ disebut sebagai state ke- $i$ pada waktu ke- $t$. Terdapat suatu peluang tetap, $P_{i j}$, yang tidak dipengaruhi oleh waktu yang dapat ditulis sebagai persamaan 4.

$$
\begin{aligned}
P\left\{X_{t+1}=j \mid X_{t}=i, X_{t-1}=i_{t-1}, \ldots, X_{1}=i_{1}, X_{0}\right. \\
\left.=i_{0}\right\}=P_{i j}
\end{aligned}
$$

dimana $i, j$ dan $t$ masing-masing menunjukkan state ke- $i$, state ke- $j$ dan waktu ke- $t$ dimana $i, j$ dan $t \geq 0$. Proses acak tersebut disebut dengan markov chain. 


\section{Peluang Transisi}

Peluang kejadian bersyarat pada state $i$ untuk berpindah ke state $j$ dikenal dengan istilah peluang transisi. Peluang bersyarat disebut peluang transisi stasioner pada MCA apabila untuk setiap $i$ dan $j$ berlaku:

$P\left\{X_{t+1}=j \mid X_{t}=i\right\}=P\left\{X_{t}=j \mid X_{0}=i\right\}$

Peluang transisi stasioner $\left(P_{i j}\right)$ menunjukkan bahwa peluang transisitidak akan berubah seiring dengan perubahan waktu. Menurut Ross (2012), peluang transisi tersebut dapat dinyatakan dalam bentuk matriks yang diberi lambang $\boldsymbol{P}$ dengan ketentuan bahwa elemen-elemen pada matriks $\boldsymbol{P}_{i j}$ bernilai positif $\left(\boldsymbol{P}_{i j} \geq 0\right)$, dan jumlahan elemenelemen pada satu baris matriks transisi tersebut harus sama dengan 1 (). Matriks peluang transisi dapat dituliskan sebagai berikut:

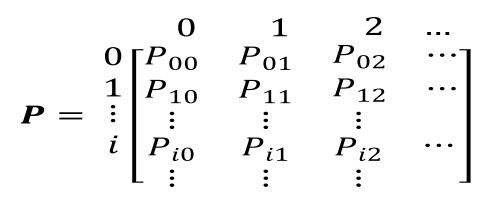

\section{Peluang Transisi n langkah}

Peluang transisi $n$ langkah merupakan peluang bersyarat pada state $i$ akan berada pada state $j$ setelah mengalami $n$ transisi yang dilambangkan dengan dan dapat ditulis sebagai berikut:

$$
P\left\{X_{t+n}=j \mid X_{t}=i\right\}=P\left\{X_{n}=j \mid X_{0}=i\right\}
$$

dimana $n=1,2,3, \ldots$ dan $t=0,1,2,3, \ldots$. Persamaan 7 dapat disederhanakan menjadi peluang transisi $n$ langkah stasioner sebagai berikut:

$$
P_{i j}^{n}=P\left\{X_{t+n}=j \mid X_{t}=i\right\}
$$

Dengan demikian, menyatakan sebuah peluang bersyarat, sehingga harus memenuhi syarat bahwa untuk semua $i$ dan $j$ dan untuk semua $i$ dan $n=0,1,2,3, \ldots$.

Matriks peluang transisi $n$ langkah dapat dituliskan sebagai berikut:

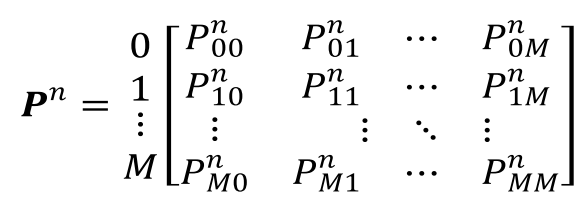

\section{Persamaan Chapman-Kolmogorov}

MenurutRoss (2012), persamaan chapmankolmogorov merupakan suatu metode yang dapat digunakan untuk menghitung peluang transisi dalam beberapa langkah ke depan dengan persamaan sebagai berikut:

$$
P_{i j}^{n+m}=\sum_{k=0}^{\infty} P_{i k}^{n} P_{k j}^{m}
$$

dimana:

$=$ peluang dari state $i$ ke state $j$ pada $n+m$ transisi

$=$ peluang dari state $i$ ke state $k$ pada $n$ transisi $=$ peluang dari state $k$ ke state $j$ pada $m$ transisi Persamaan 10 dapat disederhanakan dalam bentuk matriks transisi sebagai berikut:

$$
\boldsymbol{P}^{n+m}=\boldsymbol{P}^{n} . \boldsymbol{P}^{m}
$$

\section{Law of Large Number}

Law of Large Number (LLN) merupakan teori probabilitas yang menyatakan bahwa semakin besar jumlah sampel yang digunakan maka akan semakin mendekati rata-rata populasi (Ross, 2012). Misalkan $X_{1}, X_{2}, \ldots$, $X_{n}$ merupakan urutan variabel random i.i.d. (independent and identically distributed) dengan nilai harapan $\mu=E\left(X_{i}\right)$ maka untuk sembarang nilai $\varepsilon>0$, teori the weak law of large numbers menyatakan bahwa:

$$
P\left(\left|\frac{S_{n}}{n}-\mu\right| \geq \epsilon\right) \rightarrow 0
$$

dan teori the strong law of large numbers menyatakan bahwa:

$\frac{S_{n}}{n} \rightarrow \mu$

dengan probabilitas 1 jika $n \rightarrow \infty$, dimana $S_{n}$ $=X_{1}+X_{2}+\ldots+X_{n}$.

\section{Selang Kepercayaan}

Menurut Walpole (1982), selang kepercayaan pada umumnya memiliki dua sifat, yaitu memuat parameter sasaran dan yang kedua memiliki selang yang tidak terlalu lebar. Lebar selang kepercayaan tergantung pada ukuran sampel, dimana apabila ukuran sampel meningkat maka nilai dugaan akan semakin mendekati nilai rata-rata sebenarnya $(\mu)$. Adapun derajat selang kepercayaan yang paling umum digunakan adalah 95\% dan 99\%. Selang kepercayaan bagi rata-rata populasi $(\mu)$ apabila nilai standar deviasi $(\sigma)$ diketahui dapat dihitung menggunakan persamaan 14.

$$
\bar{x}-z_{\frac{\alpha}{2}} \frac{\sigma}{\sqrt{n}}<\mu<\bar{x}+z_{\frac{\alpha}{2}} \frac{\sigma}{\sqrt{n}}
$$

dimana menunjukkan nilai rata-rata sampel, $\mu$ menunjukkan nilai rata-rata populasi, $\sigma$ menunjukkan nilai standar deviasi populasi, 
$n$ menunjukkan banyaknya sampel dan $Z_{\alpha / 2}$ menujukkan luas daerah pada yang berada pada sisi kanan dan kiri kurva distribusi normal baku $(Z)$.

\section{HASIL DAN PEMBAHASAN}

\section{Pemilihan Presiden 2019}

Pemilihan presiden (pilpres) merupakan bagian dari rangkaian pemilu yang bertujuan untuk memilih presiden dan wakil presiden melalui pemilihan langsung oleh rakyat. Pasal 22E UUD 1945 menjelaskan bahwa pemilihan presiden diselenggarakan dalam kurun waktu lima tahun sekali dengan berlandaskan asas langsung, umum, bebas, rahasia, jujur, dan adil. Berdasarkan publikasi resmi KPU, pilpres 2019 diikuti oleh dua pasangan calon (paslon) presiden dan wakil presiden yaitu Joko Widodo - Ma'ruf Amin dengan nomor urut 01 dan Prabowo Subianto - Sandiaga Salahuddin Uno dengan nomor urut 02. Pasangan Joko Widodo - Ma'ruf Amin diusulkan dan didukung oleh partai PDIP, PKB, PKPI, Nasdem, Hanura, PPP dan Golkar. Sedangkan pasangan Prabowo Subianto - Sandiaga Salahuddin Uno diusulkan dan didukung oleh partai Gerindra, Demokrat, PKS dan PAN. Selain berkaitan dengan partai politik, pilpres tahun 2019 juga dipengaruhi oleh isu keagamaan terutama Islam. Menurut Zaprulkhan (2015), Islam bisa menjadi demokratisasi atau sebaliknya terkait dengan bidang politik. Menurut Ihsan (2017) salah satu agenda partai politik yang berasaskan Islam adalah untuk mewarnai legislasi dengan nilai-nilai keislaman termasuk legislasi untuk kepentingan publik secara umum. Kedua paslon yang bersaing sama-sama didukung oleh partai yang berasaskan Islam. Paslon nomor urut 01 didukung oleh partai PKB dan PPP, sedangkan paslon nomor urut 02 didukung oleh partai PKS.

\section{Statistika Deskriptif}

Analisis deskriptif digunakan untuk mengetahui karakteristik dari data penelitian, dalam hal ini distribusi dari data jumlah penyebutan \#2019tetapjokowi dan \#2019gantipresiden selama periode penelitian yaitu mulai tanggal 20 Agustus 2018 hingga 26 Februari 2019 (191 observasi). Informasi mengenai karakteristik dari kedua tagar tersebut disajikan dalam tabel ringkasan statistik pada Tabel 2.

Tabel 2 menunjukkan bahwa secara ratarata dan jumlah total penyebutannya, \#2019 gantipresiden terlihat lebih banyak disebutkan di media sosial dari pada \#2019tetapjokowi dalam periode penelitian. \#2019gantipresiden memiliki rata-rata jumlah penyebutan sebanyak 1.399 kali/hari dengan total selama 191 hari sebanyak 267.243 kali. Sedangkan \#2019tetapjokowi rata-rata perhari disebut sebanyak 1.297 kali dengan total sebanyak 247.730 kali. Disisi lain, \#2019gantipresiden memiliki nilai median yang lebih kecil serta memiliki penyebaran (deviasi) yang lebih besar dari pada \#2019tetapjokowi. Sehingga distribusi penyebutan \#2019ganti presiden lebih melebar dari pada distribusi penyebutan \#2019tetapjokowi. Data harian jumlah penyebutan kedua tagar tersebut disajikan secara lebih rinci dalam bentuk line chart pada Gambar 1.

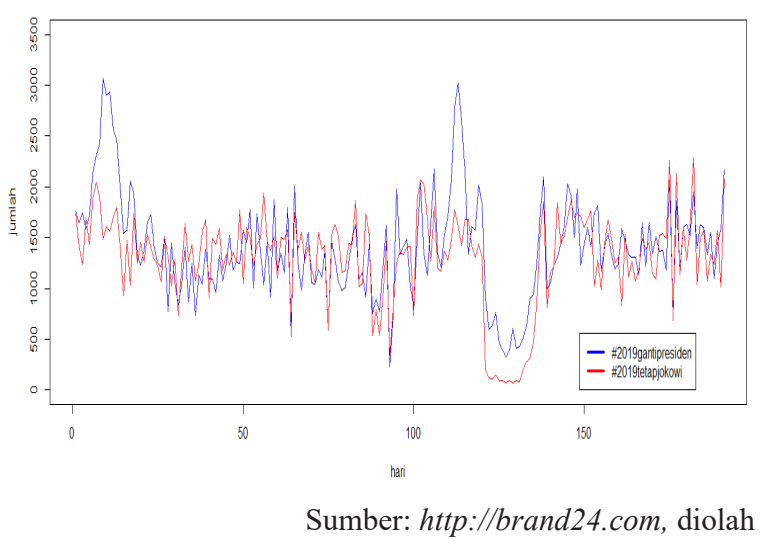

Gambar1.Linechartpenyebutan\#2019tetapjokowi dan \#2019gantipresiden selama periode 20 Agustus 2018 - 26 Februari 2019

Line chart pada Gambar 1 menunjukkan bahwa selama periode 20 Agustus 2018 hingga 26 Februari 2019, jumlah penyebutan \#2019tetapjokowi (garis merah) dan \#2019ganti presiden (garis biru) setiap harinya mengalami peningkatan dan penurunan dengan pola yang tidak teratur. Kedua tagar secara bergantian

Tabel 2. Ringkasan statistik

\begin{tabular}{lrccccc}
\hline \multicolumn{1}{c}{ Variabel } & \multicolumn{1}{c}{ Min } & Mak & Median & Rata-rata & Standar deviasi & Total \\
\hline \#2019tetapjokowi & 72 & 2.292 & 1.408 & 1.297 & 462,70 & 247.730 \\
\#2019gantipresiden & 227 & 3.070 & 1.361 & 1.399 & 511,35 & 267.243 \\
\hline
\end{tabular}


saling mengungguli satu dengan yang lainnya pada beberapa periode waktu. Penurunan ekstrim jumlah penyebutan kedua tagar terjadi pada periode data ke-121 hingga ke-135 atau pada tanggal 18 Desember 2018 hingga 01 Januari 2019. Hal tersebut diperkirakan terjadi karena adanya beberapa aktivitas pada akhir tahun seperti deadline laporan akhir tahun, liburan natal dan tahun baru, cuti bersama, dan lain sebagainya. Sehingga para user media sosial diperkirakan menjadi kurang aktif di dunia maya dibandingkan hari-hari biasanya. Pada periode tersebut, penurunan jumlah penyebutan \#2019tetapjokowi lebih besar dibandingkan dengan penyebutan \#2019gantipresiden. Jumlah penyebutan kedua tagar tersebut kembali mengalami peningkatan mulai tanggal 02 Januari 2019.

\section{Markov Chain Analysis (MCA)}

Tahap awal yang dilakukan dalam MCA adalah proses pengelompokkan data penelitian. Pengelompokkan ini didasarkan pada teori bahwa peluang transisi akan berubah setiap adanya penambahan data observasi yang baru. Di sisi lain, masa kampanye pilpres masih tersisa selama 46 hari, terhitung dari masa akhir pengumpulan data yaitu tanggal 26 Februari 2019. Sehingga peluang transisi pada hari pemilihan presiden perlu diestimasi dengan nilai rata-rata peluang transisi pada hari pemungutan suara dari masing-masing kelompok data berdasarkan teori LLN. Kelompok data pertama terdiri dari 30 data observasi mulai hari ke-1 (20 Agustus 2018) hingga hari ke-30 (18 September 2018), kelompok kedua terdiri dari 31 data observasi mulai dari hari ke-1 (20 Agustus 2018) hingga hari ke-31 (19 September 2018), kelompok ketiga terdiri dari 32 data observasi mulai dari hari ke-1 (20 Agustus 2018) hingga hari ke-32 (20 September 2018), dan seterusnya. Dengan demikian, dari 191 data observasi yang telah dikumpulkan dapat dibentuk sebanyak 161 kelompok data dengan jumlah observasi yang berbeda pada setiap kelompoknya.

\section{Penentuan State}

Terdapat tiga state yang digunakan pada penelitian ini, yaitu state "lebih dari" yang disimbolkan dengan 0, state "sama dengan" yang disimbolkan dengan 1, dan state "kurang dari" yang disimbolkan dengan 2. Data jumlah penyebutan \#2019gantipresiden akan dibandingkan dengan jumlah penyebutan \#2019tetapjokowi pada waktu yang sama untuk dapat menentukan state yang akan digunakan. Apabila jumlah penyebutan \#2019gantipresiden lebih banyak dibandingkan jumlah penyebutan \#2019tetapjokowi pada hari yang sama, maka state yang digunakan adalah state 0 . Selanjutnya apabila jumlah penyebutan \#2019gantipresiden sama dengan jumlah penyebutan \#2019tetap jokowi maka digunakan state 1 , dan apabila jumlah penyebutan \#2019gantipresiden lebih sedikit dibandingkan jumlah penyebutan \#2019 tetapjokowi maka digunakan state 2 .

\section{Matriks Peluang Transisi}

Setelah dilakukan penentuan state pada masing-masing pasangan data pada setiap kelompoknya, tahap selanjutnya adalah menghitung peluang transisi antar state pada masingmasing kelompok data yang disajikan dalam bentuk matriks yang disebut sebagai matriks peluang transisi $(\boldsymbol{P})$ yang berukuran $3 \times 3$. Pada tahap ini diperoleh 161 matriks peluang transisi dari masing-masing kelompok data. Berikut merupakan contoh peluang transisi dari kelompok data pertama (30 data observasi).

$$
\boldsymbol{P}={ }_{1}^{0} \begin{array}{ccc}
0 & 1 & 2 \\
2
\end{array}\left[\begin{array}{ccc}
0,8462 & 0 & 0,1539 \\
0 & 0 & 0 \\
1 & 0 & 0
\end{array}\right]
$$

Elemen peluang yang bersesuaian pada masing-masing matriks peluang transisi dari 161 kelompok data tersebut selanjutnya dirataratakan dengan tujuan untuk mendapatkan nilai rata-rata peluang yang mendekati nilai ekspetasi peluang dari populasi berdasarkan teori LLN. Teori LLN menyatakan bahwa rata-rata sampel akan semakin mendekati nilai ekspektasi dari populasi seiring dengan bertambahnya jumlah sampel. Matriks peluang transisi rata-rata satu langkah $(\boldsymbol{P})$ adalah sebagai berikut.

$$
\boldsymbol{P}=\begin{aligned}
& 0 \\
& 1 \\
& 2
\end{aligned}\left[\begin{array}{ccc}
0,6794 & 1 & 2 \\
0 & 0 & 0,3269 \\
0,4458 & 0 & 0,5605
\end{array}\right]
$$

Berdasarkan nilai peluang yang diperoleh pada matriks peluang transisi satu langkah $(\boldsymbol{P})$ tersebut, dapat diketahui bahwa apabila pada hari ini jumlah penyebutan \#2019gantipresiden lebih banyak daripada jumlah penyebutan \#2019tetapjokowi, maka peluang jumlah penyebutan \#2019gantipresiden akan tetap lebih banyak dari \#2019tetapjokowi pada 
satu hari yang akan datang (besok) adalah sebesar 0,6794. Selanjutnya apabila pada hari ini jumlah penyebutan \#2019gantipresiden lebih sedikit dibandingkan \#2019tetapjokowi, maka pada satu hari yang akan datang (besok) jumlah penyebutan \#2019gantipresiden hanya memiliki peluang sebesar 0,4458 untuk dapat lebih banyak dari jumlah penyebutan \#2019 tetapjokowi. Pada skenario lainnya, apabila jumlah penyebutan \#2019gantipresiden pada hari ini lebih banyak dibandingkan dengan jumlah penyebutan \#2019tetapjokowi, maka pada keesokan harinya peluang tagar tersebut untuk lebih sedikit disebutkan dari pada \#2019tetapjokowi hanya sebesar 0,3269. Namun apabila jumlah penyebutan \#2019gantipresiden pada hari ini lebih sedikit dibandingkan jumlah penyebutan \#2019tetapjokowi, maka peluang tagar tersebut akan tetap lebih sedikit disebutkan pada keesokan harinya adalah sebesar 0,5605.

Sedangkan pada state sama dengan (state 1), semua nilai peluang yang dihasilkan pada matriks peluang transisi tersebut adalah bernilai nol. Hal tersebut menunjukkan bahwa peluang jumlah penyebutan \#2019gantipresiden akan sama dengan jumlah penyebutan \#2019 tetapjokowi akan bernilai nol pada semua skenario atau kemungkinan yang ada. Hal ini dikarenakan selama periode penelitian tidak ditemukan observasi yang menunjukkan bahwa jumlah penyebutan \#2019gantipresiden sama dengan jumlah penyebutan \#2019tetapjokowi pada hari yang sama. Sebagai catatan, jumlah peluang pada setiap baris dalam setiap matriks peluang transisi adalah sama dengan satu.

\section{Matriks Peluang Transisi n langkah}

Matriks peluang transisi $n$ langkah $\left(\boldsymbol{P}^{n}\right)$ merupakan matriks peluang transisi yang digunakan untuk mengetahui peluang transisi antar state pada $n$ langkah ke depan. Matriks peluang transisi $n$ langkah dihitung menggunakan persamaan Chapman-Kolmogov (persamaan 11). Pada penelitian ini, matriks peluang transisi $n$ langkah yang dihitung adalah tepat pada hari dilaksanakannya pemilihan presiden yaitu pada tanggal 17 April 2019. Dengan demikian, banyaknya $n$ langkah pada setiap kelompok data adalah berbeda-beda tergantung pada tanggal terakhir data dikumpulkan. Pada tahap sebelumnya telah diperoleh matriks peluang transisi satu langkah $(\boldsymbol{P})$ untuk masing-masing kelompok data. Matriks peluang transisi satu langkah $(\boldsymbol{P})$ tersebut digunakan untuk menghitung matriks peluang transisi $n$ langkah atau pada hari pelaksanaan pemungutan suara. Dengan demikian, nilai $n$ untuk kelompok data pertama adalah 211, nilai $n$ untuk kelompok data kedua adalah 210, nilai $n$ untuk kelompok data ketiga adalah 209, dan seterusnya hingga nilai $n$ untuk kelompok data terakhir (kelompok 161) adalah sebanyak 50. Berikut merupakan contoh perhitungan matriks peluang transisi 211 langkah pada kelompok data pertama (30 data observasi).

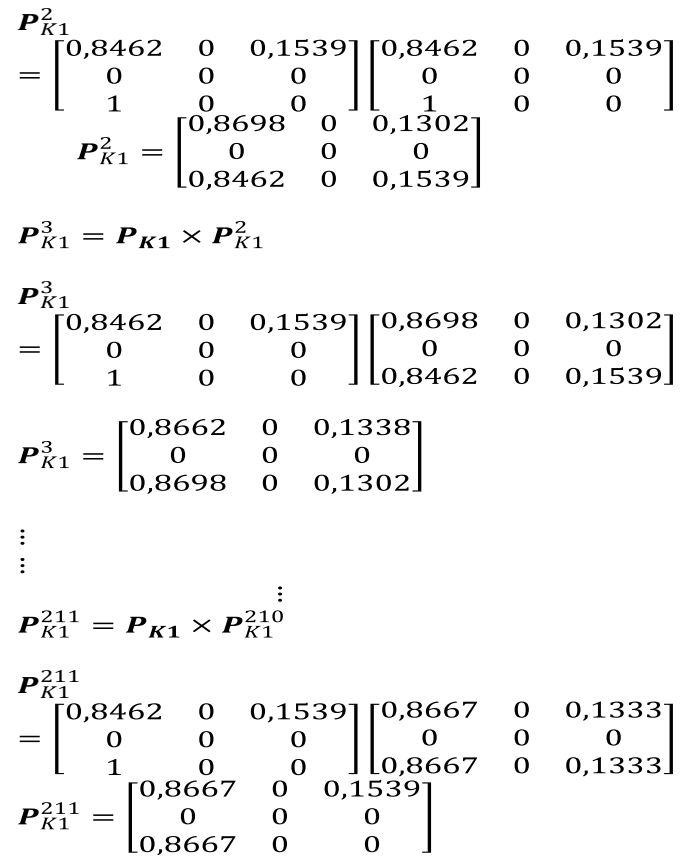

Proses perhitungan tersebut dilakukan pada semua kelompok data yang lainnya sehingga diperoleh sebanyak 161 matriks peluang transisi $\left(\boldsymbol{P}^{n}\right)$ pada hari pemilihan presiden. Selanjutnya, elemen peluang yang bersesuaian pada setiap matriks peluang transisi pada hari pemilihan presiden dari masing-masing kelompok data tersebut dirata-ratakan dan diperoleh sebuah matriks peluang transisi yang diberi nama dengan matriks peluang transisi hari pemungutan suara $\left(\boldsymbol{P}^{H}\right)$ sebagai berikut.

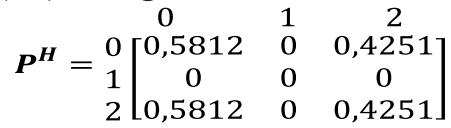

Matriks peluang transisi hari pemungutan suara $\left(\boldsymbol{P}^{H}\right)$ tersebut dapat dijabarkan secara lebih rinci pada Gambar 2.

Tanda panah pada Gambar 2 menunjukkan arah transisi antar state yang terjadi disertai dengan peluang transisi antar state yang bersang- 
kutan. Gambar 2 dan matriks peluang transisi pada hari pemungutan suara pilpres $2019\left(\boldsymbol{P}^{H}\right)$ menunjukkan bahwa besarnya peluang transisi dari state 0 (lebih dari) dan state 2 (kurang dari) ke state 0 (lebih dari) pada hari pemungutan suara pilpres adalah sama yaitu sebesar 0,5812. Demikian juga dengan peluang transisi dari state 0 (lebih dari) dan state 2 (kurang dari) ke state 2 (kurang dari) yang bernilai sama sebesar 0,4251. Dengan demikian, besarnya peluang jumlah penyebutan \#2019gantipresiden akan lebih banyak dibandingkan dengan \#2019tetapjokowi pada hari pemilihan presiden tidak terpengaruh oleh state awalnya.

0,5812

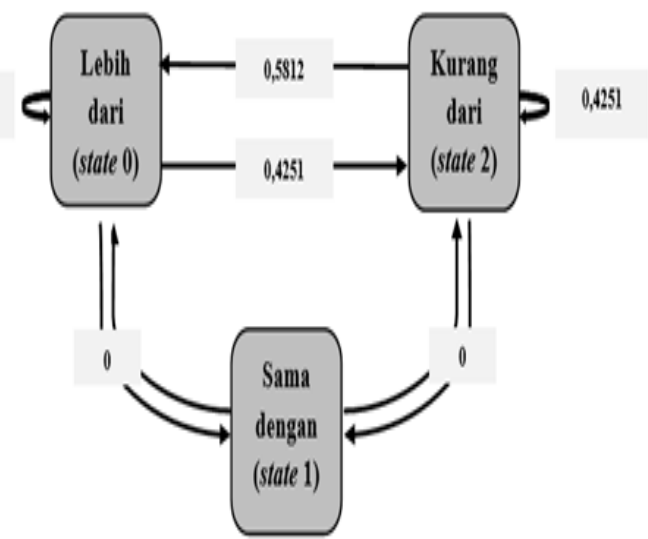

Sumber: hasil pengolahan data penulis

Gambar 2. Matriks peluang transisi pada hari pemungutan suara pilpres (17 April 2019)

Selain untuk menghitung nilai ekspektasi populasinya, peluang dalam matriks transisi pada hari pemungutan suara $\left(\boldsymbol{P}^{H}\right)$ dari 161 kelompok data juga digunakan untuk menghitung nilai standar error. Nilai standar error dari 161 matriks peluang transisi pada hari pemungutan suara $\left(\boldsymbol{P}^{H}\right)$ adalah sebesar 0,0098. Nilai standard error tersebut digunakan untuk menghitung selang kepercayaan 95\% yang ditampilkan dalam bentuk matriks sebagai berikut:

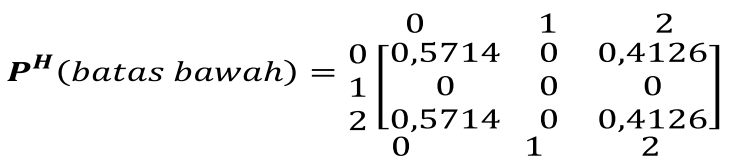

$$
\begin{aligned}
& \boldsymbol{P}^{H} \text { (batas atas) }={ }_{1}^{0}\left[\begin{array}{ccc}
0,5909 & 0 & 0,4348 \\
0 & 0 & 0 \\
0,5909 & 0 & 0,4348
\end{array}\right]
\end{aligned}
$$

Peluang transisi beserta dengan nilai selang kepercayaan $95 \%$ pada hari pemungutan suara pilpres tanggal 17 April 2019 ditampikan secara lebih rinci pada Gambar 3 dan 4.

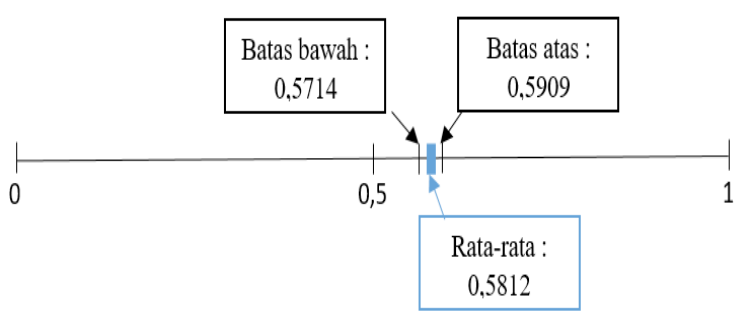

Sumber: hasil pengolahan data penulis

Gambar 3. Selang kepercayaan 95\%: penyebutan \#2019gantipresiden akan lebih banyak dari pada \#2019tetapjokowi pada hari pemungutan suara pilpres (17 April 2019)

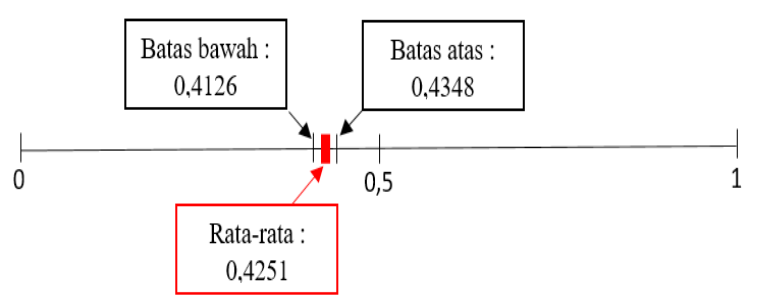

Sumber: hasil pengolahan data penulis

Gambar 4. Selang kepercayaan 95\%: penyebutan \#2019gantipresiden akan lebih sedikit dari pada \#2019tetapjokowi pada hari pemungutan suara pilpres (17 April 2019)

Berdasarkan selang kepercayaan tersebut dapatdiketahuibahwadengantingkatkepercayaan 95\%, peluang penyebutan \#2019gantipresiden akan lebih banyak dibandingkan penyebutan \#2019tetapjokowi di media sosial pada hari pemilihan presiden berada di antara interval 0,5714 hingga 0,5909. Sedangkan peluang penyebutan \#2019gantipresiden di media sosial akan lebih sedikit dari pada penyebutan \#2019tetapjokowi pada hari pemungutan suara berada di antara interval 0,4126 hingga 0,4348. Selang kepercayaan tersebut menunjukkan bahwa batas atas peluang penyebutan \#2019 gantipresiden akan lebih sedikit dari pada penyebutan \#2019tetapjokowi pada hari pemilihan presiden masih berada di bawah batas bawah peluang penyebutan \#2019gantipresiden akan lebih banyak dibandingkan penyebutan \#2019tetapjokowi. Sehingga dapat disimpulkan bahwa peluang penyebutan \#2019gantipresiden akan lebih banyak dari pada penyebutan \#2019tetapjokowi di media sosial secara nyata lebih besar dari pada peluang penyebutan \#2019gantipresiden akan lebih sedikit dari pada penyebutan \#2019tetapjokowi. Hasil analisis terhadap perbandingan kedua tagar utama 
pendukung masing-masing paslon tersebut dapat mengindikasikan bahwa pasangan calon presiden dan wakil presiden nomor urut 02, Prabowo Subianto - Sandiaga Salahuddin Uno diperkirakan akan memiliki tingkat elektabilitas dan dukungan di media sosial yang lebih tinggi pada hari pemungutan suara pilpres tahun 2019 dibandingkan paslon nomor urut 01, Joko Widodo - Ma'ruf Amin.

Hasil analisis yang diperoleh pada penelitian ini sedikit berbeda dengan hasil survei beberapa lembaga yang dilaksanakan dalam rentang waktu dua hingga tiga bulan menjelang pilpres. Dikutip dari artikel berita beritagarid yang ditulis oleh Roosyana (2019), lembaga survei Media Indonesia, Lingkaran Survei Indonesia, Pusat Kajian Kebijakan dan Pembangunan Strategis (Puskaptis), Saiful Mujani Research and Consulting dan Cyrus Network yang melakukan survei pada bulan Januari hingga Februari 2019 merilis bahwa paslon nomor urut 01 memiliki elektabilitas masing-masing sebesar $47,9 \% ; 58,7 \% ; 45,9 \% ; 54,9 \%$ dan $57,5 \%$. Sedangkan paslon nomor urut 02 memiliki elektabilitas masing-masing sebesar 38,7\%; $30,9 \% ; 41,8 \% ; 32,1 \%$ dan $37,2 \%$. Sebagai catatan, tidak semua responden dalam survei tersebut telah menentukan pilihannya. Dengan kata lain, masih terdapat pemilih yang belum menentukan pilihannya (swing voter) pada hari dilaksanakannya survei tersebut. Menurut data empiris, secara nasional porsi swing voter terbesar adalah dari generasi milenial (Perdana, 2019). Di sisi lain, penelitian dari Kurniawan (2014) menyimpulkan bahwa pengaruh persepsi pada hasil survei elektabilitas paslon capres dan cawapres adalah rendah. Hanya sekitar 8,5\% dari faktor perilaku pemilih yang dipengaruhi oleh persepsi masyarakat mengenai hasil survei, sedangkan 91,5\% lainnya dipengaruhi oleh faktor yang lain. Dengan demikian, hasil survei belum tentu dapat merepresentasikan hasil akhir pemungutan suara pilpres tahun 2019.

Sejalan dengan hasil survei elektabilitas tersebut, hasil survei popularitas yang dirilis beberapa lembaga juga menunjukkan kecenderungan yang sama. Dikutip dari artikel berita fin.co.id yang ditulis oleh Rizal (2019), lembaga survei Intermedia Research Indonesia (IRI) melakukan survei popularitas dengan menggunakan dua pola. Pertama dengan memantau jumlah berita di media massa dan kedua dengan memantau semua pembicaraan di media sosial. Hasil survei popularitas tersebut menunjukkan bahwa sepanjang tahun 2018, Joko Widodo diberitakan di media massa sebanyak 6.128.000 kali dan Prabowo Subianto diberitakan sebanyak 3.820.600 kali. Sedangkan total pembicaraan di semua kanal media untuk Joko Widodo adalah sebanyak 27.515.000 kali dan Prabowo Subianto 19.606.000 kali untuk periode waktu yang sama.

Lembaga PoliticaWave juga melakukan survei popularitas paslon capres-cawapres di media sosial yang diukur melalui 5 kategori: candidate electability, trend of awarness, share of awarness, share of citizen dan sentiment. Pada survei popularitas tersebut, candidate electability diukur melalui beberapa sub kategori yaitu sentiment index (pendapat atau perasaan dari user yang dinyatakan di media sosial), EMSS (Earned Media Share of Voice by Sentiment), unique user (jumlah user yang membicarakan sebuah isu di media sosial, tetapi bukan jumlah percakapannya), dan Buzz (percakapan yang terjadi terhadap suatu isu di media sosial).

Dikutip dari artikel berita aceh.tribunnews. com yang diedit oleh Faisal (2019), paslon 01 mengungguli paslon 02 pada survei lembaga PoliticaWave tersebut berdasarkan kategori candidate electability dengan perbandingan skor antara paslon 01 dan paslon 02 sebagai berikut: net sentiment: 677.511 vs 613.405, EMSS: 44 vs 56, unique user: 198.403 vs 137.423 dan buzz: 1.286 .533 vs 1.023.087. Selanjutnya dalam kategori trend of awareness, paslon 01 memperoleh angka 355.104, sedangkan paslon 02 mendapat angka sebanyak 325.133. Untuk kategori share of awarness, paslon 01 unggul dengan 55,7\% (1.286.533) berbanding dengan $44,3 \%$ (1.023.087) untuk paslon 02. Selanjutnya dalam kategori share of citizen, paslon 01 unggul dengan perolehan 59,1\% (198.403) dan paslon 02 mendapat 40,9\% (137.423). Terakhir, paslon 01 memperoleh angka sebanyak 676.614 untuk sentimen positif, dan 304.511 untuk sentimen negatif. Sedangkan paslon 02 mendapat sentimen positif sebanyak 470.947 angka, dan 204.841 angka untuk sentimen negatif.

Sejalan dengan studi literatur yang sudah dijelaskan pada bagian sebelumnya, Yustiningrum \& Ichwanuddin (2015) menyatakan bahwa terdapat 3 faktor yang memengaruhi partisipasi politik dan perilaku pemilih yaitu 
faktor sosiologis, psikologis dan pilihan rasional. Faktor sosiologis tersebut diantaranya berkaitan dengan isu agama dan janji-janji pemberian bantuan materi, sedangkan bagi pemilih pemula dipengaruhi oleh pilihan orang-orang di sekitarnya seperti keluarga. Faktor psikologis yang memengaruhi perilaku pemilih di antaranya berkaitan dengan adanya diskusi mengenai politik dalam lingkungan terkecil khususnya keluarga dan informasi dari media massa khususnya televisi. Faktor psikologis yang lain adalah rendahnya loyalitas terhadap partai politik serta tidak adanya identitas kepartaian pada seseorang, sehingga mudah bagi pemilih untuk berpindah ke partai yang lain. Sedangkan faktor mengenai pilihan rasional berkaitan dengan isu yang diangkat kandidat khususnya isu mengenai pemenuhan kebutuhan ekonomi. Selain ketiga faktor tersebut, Liando (2016) menambahkan bahwa sebagian besar masyarakat juga mengakui bahwa mereka memilih didorong oleh faktor transaksi dan adanya unsur kedekatan secara emosional dengan para calon kandidat peserta pemilu. Waktu pelaksanaan survei juga menjadi isu penting lainnya. Adanya lag waktu antara hari pelaksanaan survei dan hari pemungutan suara dapat menyebabkan hasil survei elektabilitas menjadi bias. Hal ini merupakan salah satu kelemahan metode survei jika dibandingkan dengan MCA.

Hasil analisis elektabilitas paslon pilpres tahun 2019 dengan metode MCA ini berbeda dengan hasil perhitungan suara secara resmi yang dikeluarkan oleh Komisi Pemilihan Umum (KPU) pada tanggal 21 Mei 2019. Pasangan dengan nomor urut 01: Joko Widodo - Ma'ruf Amin memperoleh sebanyak 85.607.362 suara sah atau sebesar $55,50 \%$ dari 34 provinsi dan 130 Panitia Pemilihan Luar Negeri (PPLN). Sedangkan pasangan nomor urut 02: Prabowo Subianto - Sandiaga Salahuddin Uno meraih sebanyak 68.650.239 suara sah atau sebesar 44,50\% (KPU, 2019). Perbedaan hasil tersebut diduga kuat disebabkan karena tagar yang digunakan dalam analisis MCA pada penelitian ini hanya terdiri satu tagar utama. Selain tagar tersebut, masih terdapat beberapa tagar lainnya yang banyak digunakan oleh pendukung kedua paslon. Lima tagar dengan jumlah penyebutan terbanyak selama periode pilpres untuk masingmasing paslon adalah \#2019tetapjokowi, \#jokowi2 periode, \#2019pilihjokowi, \#2019jokowilagi dan \#jokowilagi untuk paslon 01, dan \#2019gantipresiden, \#2019prabowopresiden, \#2019prabowosandi, \#Prabowosandi dan \#2019 presidenbaru untuk paslon 02. Data tersebut diperoleh berdasarkan hasil penelusuran pada website http://brand24.com.

Penggunaan tagar tunggal tersebut merupakan salah satu kelemahan penelitian. Sebagai catatan, penelitian ini juga tidak menganalisis efek yang dapat ditimbulkan oleh jumlah pemilih yang tidak menggunakan hak memilih mereka (golongan putih atau golput) pada pilpres tahun 2019. Penelitian dari Afnaniyati (2012) pada pemilihan kepala daerah (pilkada) tahun 2010 di Kabupaten Lamongan menyimpulkan bahwa golput dapat terjadi karena kurangnya kesadaran politik pemilih dan pemilih yang tidak berada ditempat pada saat dilaksanakan pemungutan suara. Di sisi lain, penelitian Halim (2016) pada pemilu legislatif tahun 2014 di daerah pemilihan Banggai III menyimpulkan bahwa faktor yang berpengaruh positif dan signifikan terhadap partisipasi politik masyarakat adalah status sosial dan ekonomi, situasi geografis, afiliasi orang tua, organisasi, kesadaran politik, dan dorongan kepada pemerintah.

Pada akhirnya, terlepas dari hasil analisis yang tidak terlalu akurat pada penelitian ini, metode MCA berpotensi untuk dikembangkan sebagai salah satumetode alternatif yang berbiaya rendah dalam mengukur tingkat elektabilitas calon anggota DPRD kab/kota, DPD RI, DPR RI maupun pasangan calon bupati/walikota, gubernur dan presiden peserta pemilu pada masa yang akan datang. Pemilihan tagar yang tepat dan disertai dengan penambahan jumlah tagar yang representatif diyakini akan meningkatkan tingkat akurasi hasil analisis MCA. Pengembangan metode ini diharapkan pada suatu saat akan mampu merepresentasikan hasil perhitungan suara secara resmi yang dikeluarkan oleh penyelenggara pemilu. Meskipun harus diakui bahwa saat ini jumlah penyebutan tagar tidak secara otomatis dapat dikaitkan dengan elektabilitas seorang kandidat mengingat pada beberapa kasus, tagar juga dapat digagas dan dimunculkan oleh program komputer (bot). Tagar yang digagas oleh akun bot biasanya berisi status yang sama dan diunggah pada waktu yang bersamaan oleh user yang berbeda (Fahmi, 2018). Akun bot umumnya memiliki follower yang lebih sedikit, sehingga jangkauan 
terhadap user lainnya juga cukup terbatas. Disisi lain, tagar yang digagas oleh user biasa (non bot) memiliki jangkauan yang jauh lebih luas karena user penggagas tagar tersebut memiliki follower yang lebih banyak dari pada akun bot.

Hasil riset dari Oxford Internet Institute yang bekerjasama dengan Oxford University dengan judul "The global disinformation order 2019 global inventory of organised social media manipulation" menunjukkan bahwa akun bot, cyborg dan bahkan user biasa berpotensi menyebarkan informasi yang salah melalui media sosial termasuk propogranda pro-pemerintah, pengalihan isu penting, kampanye, upaya penekanan terhadap pihak yang berseberangan, hingga untuk memecah belah. Penelitian tersebut dilakukan terhadap 70 negara yang tersebar di ketujuh benua termasuk Indonesia (Bradshaw \& Howard 2019).

Selain itu, meskipun secara prinsip MCA berbeda dengan survei, namun metode MCA juga berpotensi digunakan sebagai metode pembanding dalam mengukur tingkat elektabilitas calon anggota legislatif maupun eksekutifyang diukur melalui survei elektabilitas dan popularitas yang dilaksanakan oleh lembaga independen. Metode pembanding dalam sistem perpolitikan di Indonesia diperlukan untuk meminimalisir potensi terjadinya manipulasi tingkat elektabilitas seorang kandidat melalui hasil survei yang mungkin terjadi pada masa yang akan datang.

\section{SIMPULAN}

Penelitian ini memanfaatkan data pengguna (user) media sosial pendukung masing-masing paslon peserta pemilihan presiden 2019 melalui tagar utama keduanya yaitu \#2019tetapjokowi dan \#2019gantipresiden dengan menggunakan metode Markov Chain Analysis (MCA). Hasil analisis data menunjukkan bahwa peluang jumlah penyebutan \#2019gantipresiden akan lebih banyak dibandingkan dengan penyebutan \#2019tetapjokowi di media sosial pada hari pemungutan suara adalah sebesar 0,5812 dengan selang kepercayaan 95\% berada antara 0,5714 hingga 0,5909. Meskipun demikian, hal ini tidak menjamin bahwa paslon nomor urut 02, Prabowo Subianto-Sandiaga Salahuddin Uno, memiliki tingkat elektabilitas yang lebih tinggi dibandingkan paslon nomor urut 01 , Joko
Widodo-Ma'ruf Amin pada saat pemungutan suara mengingat data yang digunakan hanya berdasarkan satu tagar dukungan terhadap masing-masing paslon (\#2019tetapjokowi dan \#2019gantipresiden). Pemilihan serta penambahan jumlah tagar yang representatif diyakini akan meningkatkan akurasi hasil analisis MCA. Meskipun pada penelitian ini hasil analisis MCA berbeda dengan hasil perhitungan akhir KPU, namun MCA merupakan salah satu metode alternatif berbiaya rendah yang berpotensi untuk dikembangkan lebih lanjut dalam upaya mengukur tingkat elektabilitas peserta pemilu di Indonesia pada masa yang akan datang.

\section{DAFTAR PUSTAKA}

Admojo, T. (2016). Peran Partai Oposisi di Parlemen Pasca Pemilu Presiden 2014. Jurnal Politik, 1(2), 283-315. https://doi. org/10.7454/jp.v1i2.18

Afnaniyati, M. (2012). Pengaruh Tingkat Pendidikan Pemilih Pemula Terhadap Angka Golput Pada Pilkada Lamongan 2010. Jurnal Review Politik, 2(2), 244-264.

Alhamid, A., \& Perdana, A. (2018). Presidentialized Party di Indonesia: Kasus Perilaku PDI-P dalam Pencalonan Joko Widodo pada Pilpres 2014. Jurnal Politik, 3(2), 237-263. https://doi.org/10.7454/ jp.v3i2.125

Arif, M. S. (2019). Reformulasi Model Penyuaraan Paska Pemilu Serentak 2019: Studi Evaluasi Sistem Proporsional Daftar Terbuka. JWP (Jurnal Wacana Politik), 4(2), 157-171. https://doi.org/10.24198/ JWP.V4I2.25269

Bradshaw, S., \& Howard, P. N. (2019). The Global Disinformation Order 2019 Global Inventory of Organised Social Media Manipulation. Oxford: University of Oxford.

Deželan, T., \& Vobič, I. (2016). (R)evolutionizing Political Communication through Social Media. Hershey, Pennsylvania: IGI Global.

Downs, A. (1957). An Economic Theory of Democracy. New York: Harper and Row.

Fahmi, I. (2018). \#2019PrabowoPresiden Menjawab Tantangan \#2019TetapJokowi. 
Retrieved June 29, 2020, from https://pers. droneemprit.id/2019prabowopresidenmenjawab-tantangan-2019tetapjokowi/

Faisal, F. (2019, February 18). Hasil Survei Popularitas Usai Debat Kedua Pilpres, Ini Selisih Angka Jokowi-Ma'ruf dan Prabowo-Sandi. Aceh.Tribunnews.Com. Retrieved from https://aceh.tribunnews. com/2019/02/18/hasil-survei-popularitasusai-debat-kedua-pilpres-ini-selisih-angkajokowi-maruf-dan-prabowo-sandi?page $=4$

Fathurrahmi, P., \& Jatipaningrum, M. T. (2016). Konsep Markov Chains Untuk Menyelesaikan Prediksi Bencana Alam Di Wilayah Indonesia (Studi Kasus Provinsi Jawa Tengah). Jurnal Statistika Industri Dan Komputasi, 1(1), 23-27.

Fatimah, S. (2018). Kampanye sebagai Komunikasi Politik: Esensi dan Strategi dalam Pemilu. Resolusi , 1(1), 5-16.

Gunawan, B. (2018, April 30). Propaganda Politik Melalui "Hashtag" Media Sosial. Retrieved July 1, 2020, from https://news. detik.com/kolom/d-3997572/propagandapolitik-melalui-hashtag-media-sosial

Halim, R. (2016). Partisipasi Politik Masyarakat pada Pemilihan Umum Legislatif 2014 di Daerah Pemilihan Banggai III. Jurnal Review Politik, 6(2), 297-319.

Haloho, E. E., Rembang, M., \& Waleleng, G. (2016). Peran Media Sosial Terhadap Perilaku Pemilih Pemula pada Pemilihan Walikota dan Wakil Walikota Manado 2016. Acta Diurna Komunikasi, 5(3), 76-80.

Ihsan, A. B. (2017). Corak Ideologis Partai Politik Islam. Jurnal Review Politik, 7(1), 1-25.

KPU. Keputusan KPU Tentang Penetapan Calon Presiden dan Wakil Presiden Terpilih Dalam Pemilihan Umum Tahun 2019, Pub. L. No. 1185/PL.01.9-Kpt./06/KPU/ VI/2019 (2019). Indonesia. Retrieved from https://jdih.kpu.go.id/data/data_kepkpu/ KPT 1185 THN 2019.pdf

Kurniawan, D. (2014). Pengaruh Hasil Survei Tentang Elektabilitas Capres-Cawapres 2014 Terhadap Perilaku Pemilih di Surabaya. Jurnal Review Politik, 5(1), 126-151.
Lakshmi, G., \& Jyothi, M. (2020). Application of Markov Process for Prediction of Stock Market Performance. International Journal of Recent Technology and Engineering, 8(6), 1516-1519. https://doi.org/10.35940/ ijrte.F7784.038620

Liando, D. M. (2016). Pemilu dan Partisipasi Politik Masyarakat (Studi Pada Pemilihan Anggota Legislatif dan Pemilihan Presiden dan Calon Wakil Presiden di Kabupaten Minahasa Tahun 2014). Jurnal LPPM Bidang EkoSosBudKum, 3(2), 14-28.

Messina, C. (2010). Hashtags. Retrieved July 1, 2020, from http://twitter.pbworks.com/w/ page/1779812/Hashtags

Mujani, S., Liddle, R. W., \& Ambardi, K. (2012). Kuasa Rakyat: Analisis tentang perilaku memilih dalam pemilihan Legislatif dan Presiden Indonesia Pasca-Orde Baru. Jakarta: Mizan.

Mulyadi, U., \& Fitriana, L. (2018). Hashtag (\#) as Message Identity in Virtual Community. Jurnal The Messenger, 10(1), 44-53. https:// doi.org/10.26623/themessenger.v10i1.671

Ndruru, S. (2014). Penerapan Rantai Markov Terhadap Perubahan Indeks Harga Saham. Skripsi. Universitas Sumatera Utara.

Nimmo, D. (2010). Jual Komunikasi Politik Khalayak dan Efek. Bandung: Remaja Rosdakarya.

Nurdiansyah, F. (2018). Marketing Politik DPP Partai Gerindra pada Pemilu Legislatif 2014. Politika: Jurnal Ilmu Politik, 9(1), 60-70. https://doi.org/10.14710/ politika.9.1.2018.60-70

Perdana, K. (2019). Efektivitas Alat Peraga Kampanye Calon Anggota Legislatif: Studi Pendahuluan Pemasaran Politik pada Generasi Milenial di Provinsi Lampung, Indonesia. JWP (Jurnal Wacana Politik), 4(1), 44-54. https://doi.org/10.24198/JWP. V4I1.21078

Purboningsih, S. D. (2015). Gerakan Sosial Baru Perspektif Kritis: Relawan Politik Dalam Pilpres 2014 Di Surabaya. Jurnal Review Politik, 5(1), 100-125.

Puspita, A. (2018). Politik "Labelisasi” di Balik Tagar. Retrieved July 1, 2020, from https:// pers.droneemprit.id/2019tetappancasila/ 
Rizal, R. (2019, January 1). IRI Rilis Survei Popularitas Capres, Begini Hasilnya . Fajar Indonesia Network. Retrieved from https://fin.co.id/2019/01/01/iri-rilis-surveipopularitas-capres-begini-hasilnya/

Roosyana, R. (2019, March 12). Pilpres 2019 jadi pertaruhan kredibilitas lembaga survei. Beritagar.Id. Retrieved from https:// beritagar.id/artikel/berita/pilpres-2019-jadipertaruhan-kredibilitas-lembaga-survei

Ross, S. M. (2012). A First Course in Probability (Ninth Edition). New Jersey: Prentice Hall, Inc.

Roth, D. (2008). Studi pemilu empiris : Sumber, teori-teori, instrumen dan metode. Jakarta: Friedrich-Naumann-Stiftung Fur Die Freiheit.

Statista. (2019). Indonesia: number of social network users 2017-2023. Retrieved June 28, 2020, from https://www.statista. com/statistics/247938/number-of-socialnetwork-users-in-indonesia/

Suwarko, A. (2015). Penyederhanaan Sistem Kepartaian Pasca Orde Baru. Jurnal Review Politik, 3(2), 279-297.
Triono, T. (2017). Menakar Efektivitas Pemilu Serentak 2019. JWP (Jurnal Wacana Politik), 2(2), 156-164. https://doi. org/10.24198/jwp.v2i2.14205

Walpole, R. E. (1982). Introduction to statistics. London: Macmillan Pub. Co.

Wiryanto, W. (2000). Teori Komunikasi Massa. Jakarta: PT Gramedia Widiasarana Indonesia.

Yustiningrum, R. E., \& Ichwanuddin, W. (2015). Political Participation and Voting Behavior in General Election 2014. Jurnal Penelitian Politik, 12(1), 117-135.

Zaprulkhan, Z. (2015). Dinamika Pemikiran Politik Islam di Indonesia. Jurnal Review Politik, 3(2), 153-167.

Zinaida, R. S., \& Maharani, D. (2015). Pengaruh Sosial Media Terhadap Sikap Politik Pemula di Kota Palembang (Studi Kasus Pemilih Pemula di Kota Palembang, Sumatera Selatan Pada Masa Pemilihan Umum 2014). In Konferensi nasional komunikasi 2015 (pp. 1-10). Solo. 